\title{
MODIFICATION OF CLAYEY SOIL USING FLY ASH
}

\author{
Ravi Kumar Sharma ${ }^{1}$, Babita Singh ${ }^{2}$ \\ ${ }^{1}$ Professor, ${ }^{2}$ P.G. Student, Department of Civil Engineering, National Institute of Technology, H.P., India, \\ rksnithp61@gmail.com, babitassingh1@gmail.com
}

\begin{abstract}
Soil modification refers to the process of enhancing physical, chemical and mechanical properties of soil to maintain its stability. In this research, an attempt has been made to improve the engineering properties of locally available clayey soil by making a composite mix with waste river sand and fly ash in appropriate proportions. A series of proctor compaction tests, unconfined compressive strength (UCS) tests and falling head permeability tests were carried out. It was revealed that both strength and permeability characteristics of clayey soil improve on addition of local sand and fly ash. Thus, a suitable mix proportion of clayey soil-sand-fly ash for various geotechnical applications like construction of embankments, low cost rural roads etc. can be obtained. The main objective of this research work is to obtain an improved construction material by making the best use of available clayey soil \& sand and to make the effective utilization of fly ash.
\end{abstract}

Keywords: Clayey soils, river sand, fly ash, UCS and permeability.

\section{INTRODUCTION}

Most of the electricity generation in our country is from coal based thermal power plants which yield fly ash as a byproduct. Government of India is making efforts for its safe management and disposal under "FLY ASH MISSION" since 1994. Nowadays, fly ash is used in the manufacture of cement, bricks, roads \& embankments, in the works of mine filling and reclamations, etc. Status of fly ash generation and its utilization in India for the year 2011-2012 indicates 54.53\% utilization (36.26 Million-tonnes utilized out of 66.49 Milliontonnes of fly ash generated). Thus, a large percentage of fly ash produced in the country still remains unutilized giving rise to the need of producing a large number of technologies for its effective utilization. Many research and development efforts in the field of geotechnical applications are in progress for gainful utilization of fly ash.

Bhuvaneshwari [2005] revealed that workability ameliorates with $25 \%$ fly ash and also the maximum dry density is obtained for this proportion. Rao et al [2008] observed that on adding fly ash maximum dry density increases and optimum moisture content decreases up to a certain fly ash content called "optimum fly ash content" while the trend gets reversed on increasing the fly ash content beyond this optimum fly ash content. On the basis of unconfined compressive strength test study Brooks [2009] investigated that failure stress and strain increases by $106 \%$ and $50 \%$ respectively on addition of fly ash from 0 to $25 \%$. Sharma et al [2012] concluded that UCS and CBR of soil increases substantially on addition of $20 \%$ fly ash and $8.5 \%$ lime. Bose [2012] reported that fly ash has a good potential of improving the engineering properties of expansive soil. Takhelmayum et al [2013] exhibit the improvement in strength characteristics of soil on adding coarse fly ash. Many more researchers like Ingles and Metcalf [1972], Mitchell and katti [1981], Brown [1996], Cokca [2001], Consoli et al [2001], Senol et al [2002], Pandian et al [2002], Phanikumar [2004], Kumar[2004], Edil et al [2006], Ahmaruzzaman [2010], Muntohar [2012], etc. shows the effectiveness of use of fly ash in improving the properties of soil. From the above research review it is seen that there is a vast scope of utilization of fly ash as an additive in the improvement of geotechnical properties of soil

\section{ENGINEERING PROPERTIES OF MATERIALS}

\section{USED}

Locally available clayey soil categorized as CL (low plasticity clay) type according to ASTM D2487-10 is used in this experimental program. Basic index properties of clay are given in table 1 .

Table-1: Physical properties of clay

\begin{tabular}{|l|l|}
\hline PROPERTY TESTED & VALUE \\
\hline Specific gravity & 2.617 \\
\hline Liquid limit (\%) & 42.89 \\
\hline Plastic limit (\%) & 22.55 \\
\hline Plasticity index (\%) & 20.34 \\
\hline Soil classification & $\mathrm{CL}$ \\
\hline Optimum moisture content $(\%)$ & 12.0 \\
\hline Maximum dry density $(\mathrm{gm} / \mathrm{cc})$ & 1.926 \\
\hline Coefficient of permeability $(\mathrm{cm} / \mathrm{s})$ & $1.44 \times 10-7$ \\
\hline Unconfined compressive strength $(\mathrm{kPa})$ & 246.48 \\
\hline
\end{tabular}


Table-2: Physical properties of sand

\begin{tabular}{|l|l|}
\hline PROPERTY TESTED & VALUE \\
\hline Specific gravity & 2.631 \\
\hline Coefficient of uniformity, $\mathrm{Cu}$ & 1.79 \\
\hline Coefficient of curvature, $\mathrm{Cc}$ & 1.03 \\
\hline Optimum moisture content $(\%)$ & 6.78 \\
\hline Maximum dry density $(\mathrm{gm} / \mathrm{cc})$ & 1.589 \\
\hline Coefficient of permeability $(\mathrm{cm} / \mathrm{s})$ & $2.644 \times 10-3$ \\
\hline
\end{tabular}

The sand used in this experimental investigation is Beas river sand which is poorly graded. Basic properties of sand are given in table 2 . Fly ash used in this study is class F category fly ash collected from Ropar thermal power plant. Class F fly ash is obtained from the burning of anthracite and bituminous coals. It has low calcium content. Chemical and physical properties of fly ash used in this study are given in table 3 and table 4 respectively.

Table-3: Chemical composition of fly ash

\begin{tabular}{|l|l|}
\hline CONSTITUENT & Percentage \\
\hline Silica $(\mathrm{SiO} 2)$ & 59.50 \\
\hline Alumina $(\mathrm{Al} 2 \mathrm{O} 3)$ & 27.10 \\
\hline Iron oxide $(\mathrm{Fe} 2 \mathrm{O} 3)$ & 7.36 \\
\hline Calcium oxide $(\mathrm{CaO})$ & 2.30 \\
\hline Magnesium Oxide $(\mathrm{MgO})$ & 0.64 \\
\hline Sulphur tri oxide $(\mathrm{SO} 3)$ & 0.85 \\
\hline Loss of ignition & 2.25 \\
\hline
\end{tabular}

Table-4: Physical properties of fly ash

\begin{tabular}{|l|l|}
\hline PROPERTY TESTED & VALUE \\
\hline Specific gravity & 1.968 \\
\hline Liquid limit $(\%)$ & 40.1 \\
\hline Optimum moisture content $(\%)$ & 31.5 \\
\hline Maximum dry density $(\mathrm{gm} / \mathrm{cc})$ & 1.167 \\
\hline Coefficient of permeability $(\mathrm{cm} / \mathrm{s})$ & 5.557 x $10-5$ \\
\hline
\end{tabular}

\section{TESTING METHODOLOGY ADOPTED}

All the laboratory tests were conducted conforming to ASTM standards shown in table 5.

Table-5: ASTM standards for different tests

\begin{tabular}{|l|l|}
\hline TEST & ASTM STANDARD \\
\hline Hydrometer analysis & ASTM D422-63 \\
\hline Standard Proctor test & ASTM D698-07e1 \\
\hline Specific gravity compressive & ASTM D854-10 \\
\hline $\begin{array}{l}\text { Unconfined } \\
\text { strength test (UCS) }\end{array}$ & ASTM D2166-13 \\
\hline Soil Classification (USCS) & ASTM D4318-10 \\
\hline Consistency limit tests & \\
\hline
\end{tabular}

\begin{tabular}{|l|l|}
\hline Particle size distribution & ASTM D6913-04 \\
\hline Falling head permeability test & ASTM D5084-03 \\
\hline
\end{tabular}

The laboratory tests for the present research were carried out into following phases:

- A series of Proctor compaction tests were carried out on clay with different percentages of sand i.e. $10 \%$, $20 \%, 30 \%$ \& $40 \%$. Then, the optimum mix proportion (the proportion with maximum MDD) was chosen for further modification.

- The optimum clay-sand mix obtained was mixed with different percentages of fly ash i.e. $10 \%, 15 \%, 20 \%$, and $25 \%$ and standard proctor compaction test was carried out on each mix to obtain suitable clay-sandfly ash mix.

- After choosing the optimum combinations of claysand \& clay-sand-fly ash, they were tested for strength characteristics (unconfined compressive strength, UCS) and permeability characteristics.

\section{RESULTS AND DISCUSSIONS}

\subsection{Particle Size Distribution Analysis:}

Particle size distribution curves of clay, sand and fly ash are shown in fig 1. It is revealed from the figure that clay and fly ash are uniformly graded in nature i.e. they are not having good representation of all particle sizes with fly ash having larger range of finer particles while the sand is poorly graded in nature.

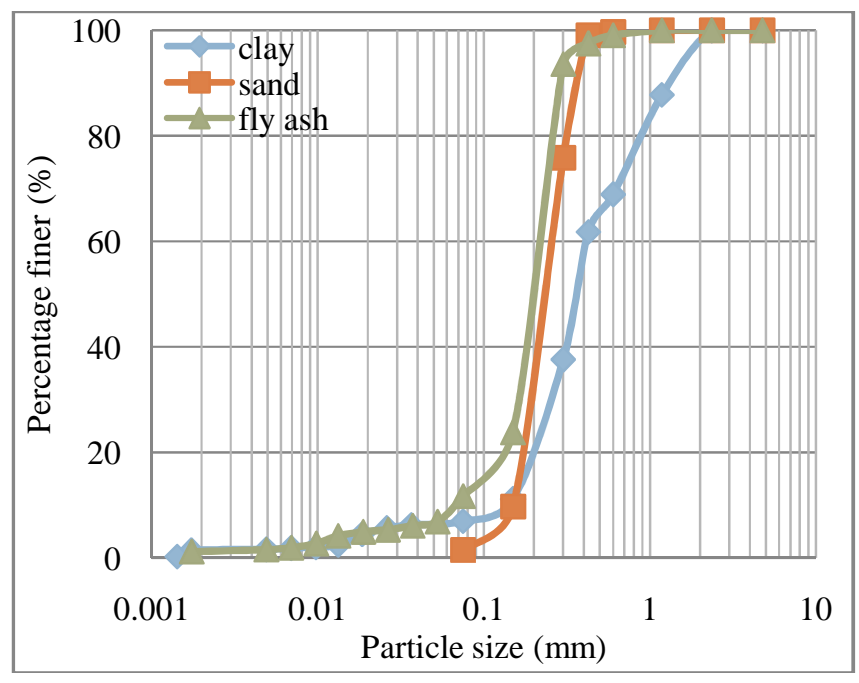

Fig-1: Particle size distribution of clay, sand and fly ash.

\subsection{Compaction Characteristics:}

The maximum dry density of clayey soil used in this study was $1.926 \mathrm{gm} / \mathrm{cm} 3$ with the optimum moisture content of $12 \%$. 


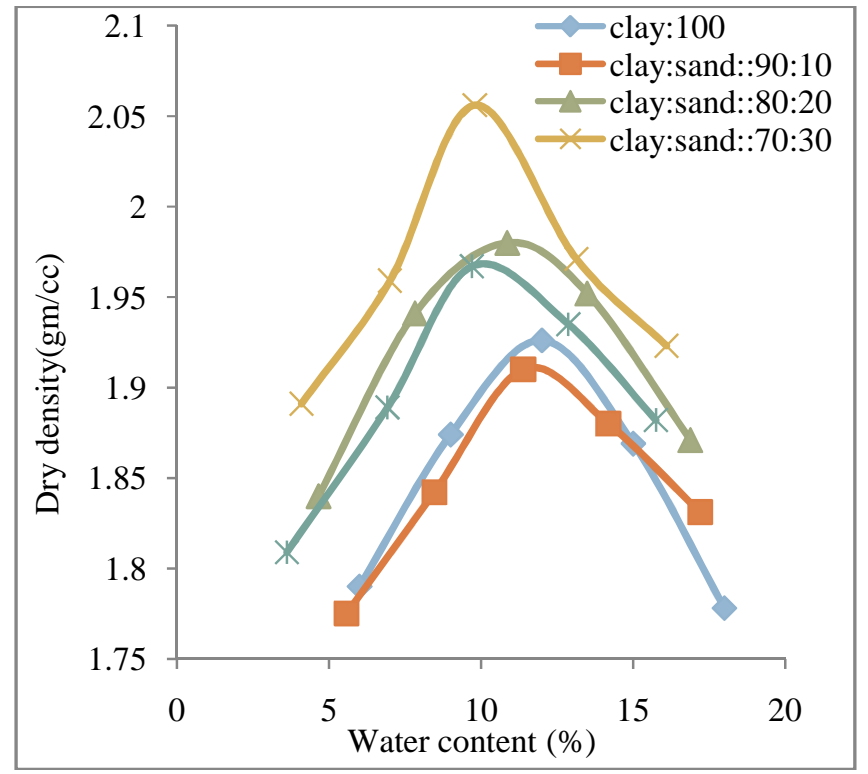

Fig-2: Compaction characteristics of clay-sand mixes

On mixing the clay with sand from $10 \%$ to $40 \%$ in the increments of $10 \%$, the maximum dry density of the mix increases from $1.910 \mathrm{~g} / \mathrm{cm} 3$ to $2.056 \mathrm{~g} / \mathrm{cm} 3$ up to $30 \%$ sand content while it decreases from $2.056 \mathrm{~g} / \mathrm{cm} 3$ to $1.967 \mathrm{~g} / \mathrm{cm} 3$ for $40 \%$ sand content as shown in figures 2 and 3. It occurred because initially the void spaces created in the mix on adding sand was filled with the fine clay particles up to a certain percentage of sand causing increase in the maximum dry densities and after that, the extra amount of sand added leads to the segregation resulting in the decrease of maximum dry density.

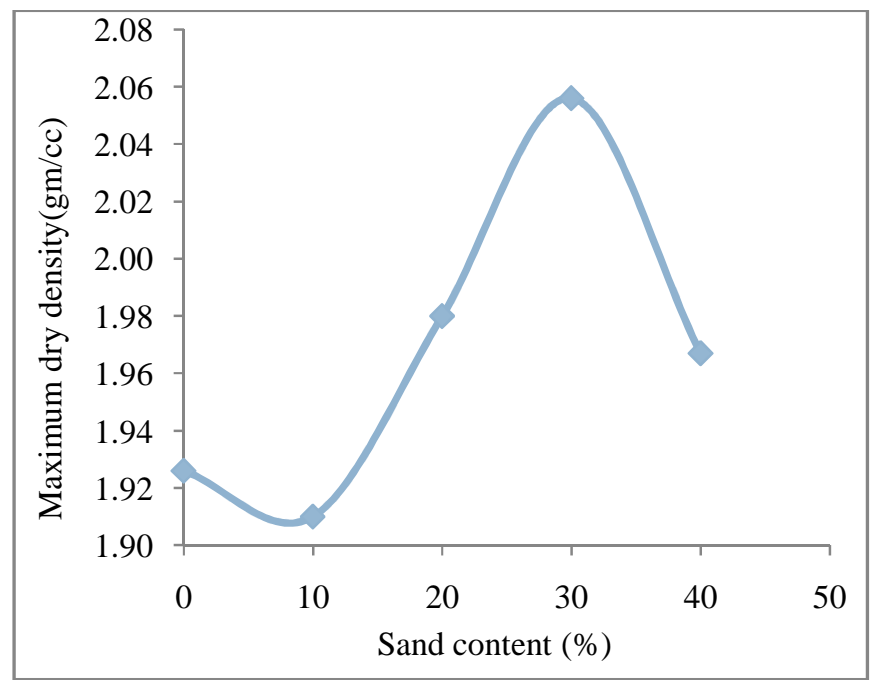

Fig-3: Variation of maximum dry density of clay-sand composite with sand content

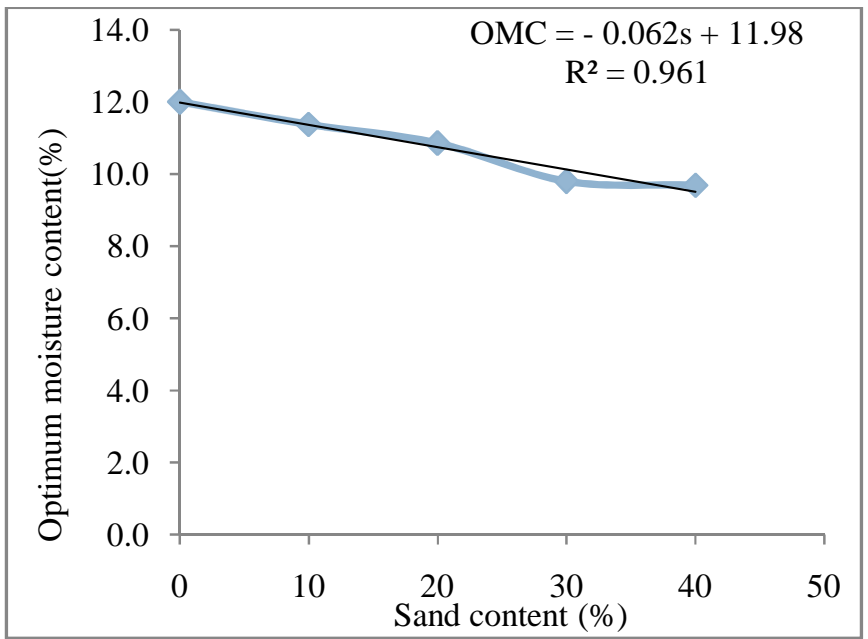

Fig-4: Variation of optimum moisture content of clay-sand composite with sand content

The optimum moisture content (OMC) of the clay-sand mix decreases as the sand content increases as shown in figure 4. This happened because of the less specific surface area of the sand particles i.e. their coarse grained nature because of which they require less water to achieve maximum dry density. On linear regression, the relationship obtained with the percentage of variation of sand in the composite clay-sand mix and the optimum moisture content of the composite mix; in which optimum moisture content is represented by 'OMC' and percentage of sand is represented by ' $\mathrm{s}$ '; can be given by:

$$
\mathrm{OMC}=-0.062 \mathrm{~s}+11.98
$$

$$
\mathrm{R}^{2}=0.961
$$

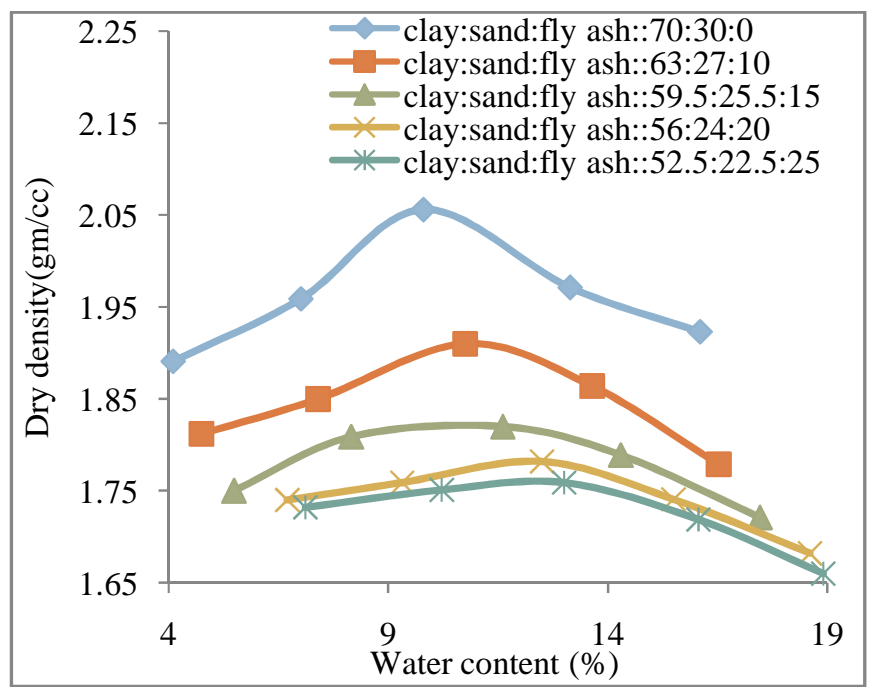

Fig-5: Compaction characteristics of clay-sand-fly ash mix 


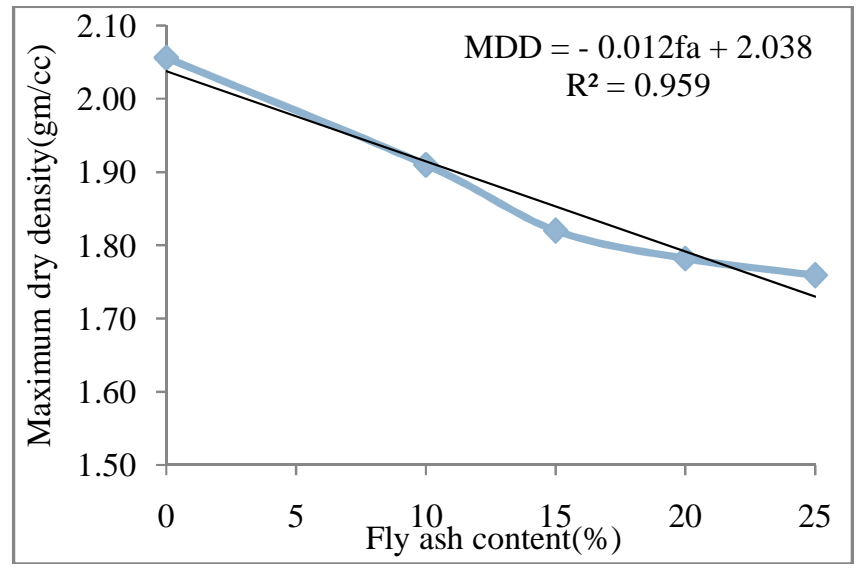

Fig-6: Variation of maximum dry density of clay-sand-fly ash mix with fly ash content

Then, $70 \%$ clay- $30 \%$ sand mix with maximum dry density of $2.043 \mathrm{~g} / \mathrm{cm} 3$ which was selected as the optimum clay-sand mix was further mixed with different percentages of fly ash varying from $10 \%$ to $25 \%$ in the increments of $5 \%$ each. The maximum dry density decreases from $1.913 \mathrm{~g} / \mathrm{cm} 3$ to 1.761 $\mathrm{g} / \mathrm{cm} 3$ on varying fly ash content from $10 \%$ to $25 \%$ as shown in figures 5 and 6.

It probably happened because the specific gravity of fly ash is lower than the specific gravity of clayey soil and sand used. Therefore, the mix clay:sand:flyash:: 63:27:10 was chosen as the most appropriate mix proportion.

On linear regression, the relationship obtained with the percentage of variation of fly ash in the composite clay-sand fly ash mix and the maximum dry density of the composite mix; in which maximum dry density is represented by 'MDD' and percentage of fly ash is represented by 'fa'; can be given by:

$$
\begin{gathered}
\text { MDD }=-0.012 \mathrm{fa}+2.038 \\
\mathrm{R}^{2}=0.959
\end{gathered}
$$

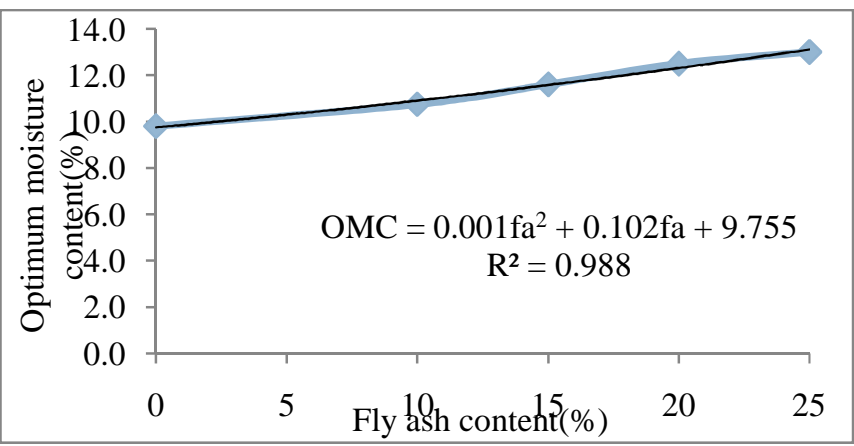

Fig-7: Variation of optimum moisture content of clay-sand fly ash mix with fly ash content.
The optimum moisture content of the mix improves on increasing the fly ash content because fly ash particles have large specific area and hence require more water for sufficient lubrication to achieve maximum dry density. The trend of variation of optimum moisture content on increasing the percentage of fly ash is shown in figure 7 .

On polynomial regression, the relationship obtained with the percentage of variation of fly ash in the composite clay-sand fly ash mix and the optimum moisture content of the composite mix; in which optimum moisture content is represented by 'OMC' and percentage of fly ash is represented by 'fa'; can be given by:

$$
\mathrm{OMC}=0.001 \mathrm{fa} 2+0.102 \mathrm{fa}+9.755
$$

$$
\mathrm{R}^{2}=0.988
$$

\subsection{Unconfined Compressive Strength Test Results:}

The unconfined compressive strength tests were conducted on the optimum mixes obtained from standard compaction. The size of the samples prepared were of aspect ratio 2 i.e., $38 \mathrm{~mm}$ diameter and $76 \mathrm{~mm}$ length. The stress-strain behaviors of different composites are shown in figure 8. Unconfined compressive strength of clay used in this study was 246.48 $\mathrm{kN} / \mathrm{m} 2$. For the optimum clay-sand mix, UCS increased to $397.10 \mathrm{kN} / \mathrm{m}^{2}$ and it increased to $290.68 \mathrm{kN} / \mathrm{m} 2$ for the most appropriate clay-sand-fly ash mix as shown in figure 9 .

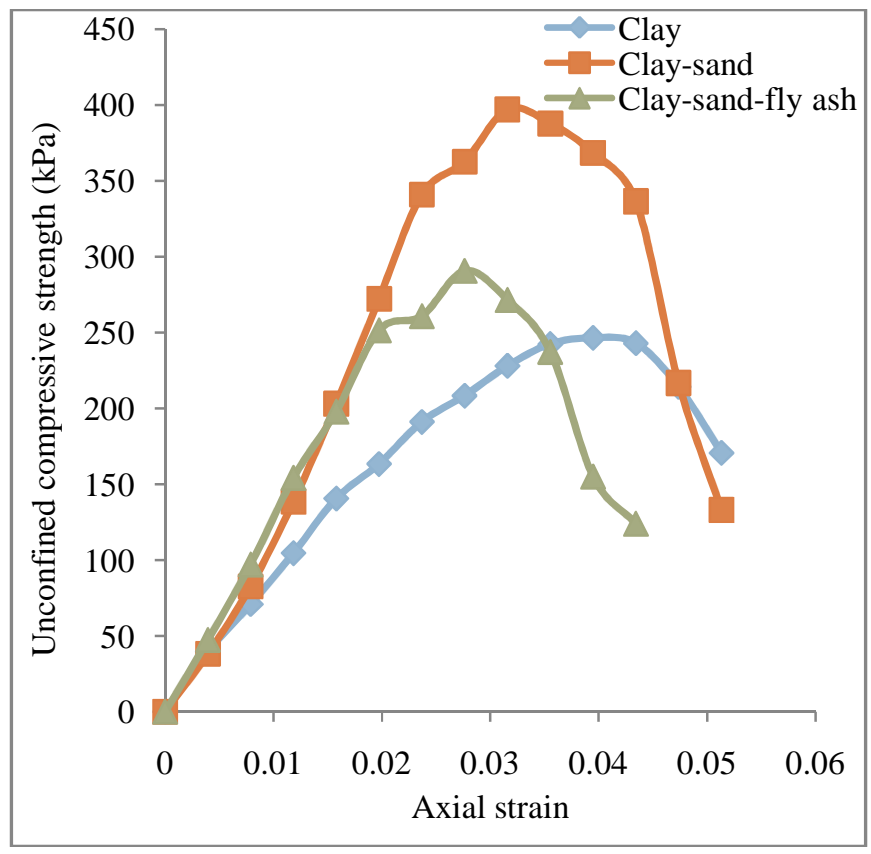

Fig-8: Stress-strain behavior of clay, clay-sand and clay-sandfly ash mix. 


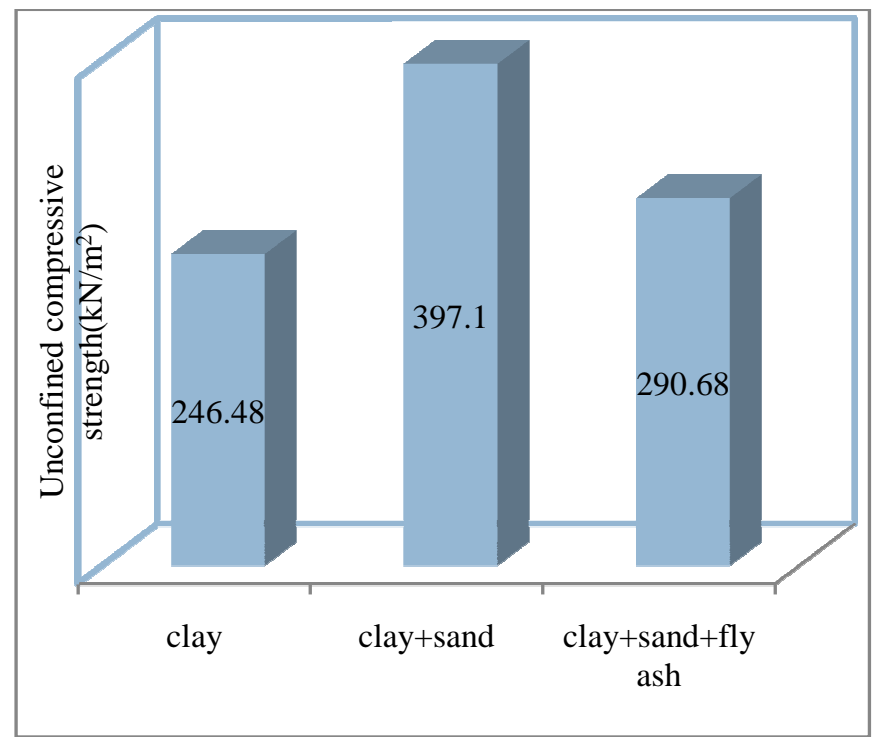

Fig-9: Unconfined compressive strength of clay, clay-sand and clay-sand-fly ash mix

Though, the unconfined compressive strength of final appropriate composite mix of clay-sand-fly ash is less than the unconfined compressive strength of the optimum clay-sand mix, it is higher than the unconfined compressive strength of pure clay. Reasons for the decrement of unconfined compressive strength of optimum clay-sand-fly ash mix from the unconfined compressive strength of optimum clay-sand mix can be less specific gravity and lesser maximum dry density of fly ash in comparison to those of clay and sand. Also, fly ash is a comparatively weaker material.

\subsection{Permeability Test Results:}

The coefficient of permeability of clay, sand and fly ash determined by using falling head permeability test are 1.447 $\mathrm{x} 10-7 \mathrm{~cm} / \mathrm{s}, 2.644 \mathrm{x} 10-3 \mathrm{~cm} / \mathrm{s} \& 5.557 \mathrm{x} 10-5 \mathrm{~cm} / \mathrm{s}$ respectively. The coefficient of permeability of clay increases on addition of sand and fly ash. The variation of coefficient of permeability of optimum mixes is shown in table 6 .

Table-6: Coefficient of permeability of optimum mixes

\begin{tabular}{|l|l|}
\hline OPTIMUM MIXES & $\begin{array}{l}\text { COEFFICIENT OF } \\
\text { PERMEABILITY }(\mathrm{cm} / \mathrm{s})\end{array}$ \\
\hline $100 \%$ clay & $1.44 \times 10-7$ \\
\hline $70 \%$ clay: $30 \%$ sand & $6.55 \times 10-7$ \\
\hline $\begin{array}{l}63 \% \text { clay: } 27 \% \text { sand: } 10 \% \\
\text { fly ash }\end{array}$ & $1.688 \times 10-6$ \\
\hline
\end{tabular}

This increase in permeability occurs because on the addition of fly ash the maximum dry density of the optimum clay-sandfly ash mix decreases due to the lesser specific gravity of fly ash. Again, since fly ash particles are mostly rounded and uniformly graded, the permeability of the composite optimum clay-sand-fly ash mix gets increased.

\section{CONCLUSIONS}

The conclusions drawn from this study are as follows:

1. The highest value of maximum dry density is achieved for $70 \%$ clay: $30 \%$ sand and hence this is the most appropriate clay-sand mix. [Figure- 2]

2. On increasing the sand content, the optimum moisture content of clay-sand mix decreases because sand particles are coarse grained in nature. [Figure-4]

3. Maximum dry density of clay-sand mix initially increases and then decreases on increasing the sand content because up to a certain percentage of sand, the void spaces between the sand particles get filled by the fine clay particles and further increase in sand content causes segregation in the mix, reducing the maximum dry density. [Figure-3]

4. Maximum dry density of clay-sand-fly ash mix decreases as the content of fly ash is increased because of the lower specific gravity of fly ash in comparison to that of clay and sand [Figure-6] while optimum moisture content shows reverse trend because of the larger specific surface area of generally round shaped fly ash particles as compared to those of clay [Figure-7].

5. The appropriate clay-sand-fly ash mix considered is clay: sand: fly ash:: 63\%:27\%:10\% [Figure-5].

6. Strength and permeability characteristics of clayey soil improved on addition of sand and fly ash in appropriate proportions.

7. The coefficient of permeability of the most appropriate mix i.e. clay: sand: fly ash:: 63:27:10 obtained from this study increased to the value $1.688 \times 10^{-6} \mathrm{~cm} / \mathrm{s}$ from $1.44 \times 10^{-7} \mathrm{~cm} / \mathrm{s}$ because fly ash particles are mostly spherical. [Table-6]

8. The value of failure stress of optimum clay-sand mix increases by $61.11 \%$ in comparison to that of pure clay. The value of failure stress obtained for the final composite mix of clay-sand-fly ash is lesser than that of the optimum clay-sand mix but still it is higher than that of pure clay by $17.93 \%$ [Figure-9].

\section{REFERENCES}

[1] Ahmaruzzaman, M., "A review on the utilization of fly ash," Progress in Energy and Combustion Science, Vol. 36, No. 3, pp. 327-363, 2010.

[2] ASTM D422-63, "Standard test methods for hydro meter analysis of soils," American Society for Testing of Materials, Pennsylvania, PA, USA.

[3] ASTM D698-07e1, "Standard test methods for laboratory compaction characteristics of soil using standard effort," American Society for Testing of Materials, Pennsylvania, PA, USA. 
[4] ASTM D854-10, "Standard test methods for specific gravity of soil," American Society for Testing of Materials, Pennsylvania, PA, USA.

[5] ASTM D2166-13, "Standard test methods for unconfined compressive strength test for soils," American Society for Testing of Materials, Pennsylvania, PA, USA.

[6] ASTM D2487-11, "Standard practice for classification of soils for engineering purposes (unified soil classification system)," American Society for Testing of Materials, Pennsylvania, PA, USA.

[7] ASTM D4318-10, "Standard test methods for liquid limit, plastic limit, and plasticity index of soils," American Society for Testing of Materials, Pennsylvania, PA, USA.

[8] ASTM D5084-03, "Standard test methods for falling head permeability test of soils," American Society for Testing of Materials, Pennsylvania, PA, USA.

[9] ASTM D5239-2004, "Standard practice for characterizing fly ash for use in soil stabilization," American Society for Testing of Materials, West Conshohocken, PA, USA.

[10] ASTM D6913-04, "Standard test methods for particle size distribution of soils," American Society for Testing of Materials, Pennsylvania, PA, USA.

[11] Bhuvaneshwari, S., Robinson, R.G. and Gandhi, S.R., "Stabilization of expansive soils using fly ash," Fly Ash India, Fly Ash Utilization Programme (FAUP), TIFAC, DST, New Delhi, 2005.

[12] Bose, B., "Geo engineering properties of expansive soil stabilized with fly ash," Electronic Journal of Geotechnical Engineering, Vol. 17, Bund. J, 2012

[13] Brooks, R.M., "Soil stabilization with fly ash and rice husk ash," International Journal of Research and Reviews in Applied Sciences, Vol. 1, Issue 3, 2009.

[14] Brown, R.W. Practical Foundation Engineering Handbook. Mc Graw Hill, New York, 1996.

[15] Cokca, E., "Use of class $\mathrm{C}$ fly ash for the stabilization of an expansive soil," Journal of Geotechnical and Geoenvironmental Engineering, ASCE 127(7):568573, 2001.

[16] Consoli, N.C., Prietto, P.D.M., Carraro, J.A.H. and Heinech," Behaviour of compacted Soil-Fly AshCarbide Lime Mixtures", Journal of Geotechnical and Geoenvironmental Engineering ASCE 127(9), 574584, 2001.

[17] Edil, T.B., Acosta, H.A., and Benson, C.H., "Stabilizing soft fine grained soils with fly ash," Journal of Materials in Civil Engineering, ASCE 18(2), 283-294, 2006.

[18] Ingles, O.G., and J.B. Metcalf, "Soil stabilization Principles and Practice", Butterworth, Sydney, Australia.

[19] Kumar, B.R.P., Sharma R.S., "Effect of fly ash on engineering properties of expansive Soils," J Geotech
Geoenviron Eng, ASCE 130(7), 764-767, 2004.

[20] Mitchell, J.K. and R.K. Katti, "Soil improvement: state of the art report. Proc. $10^{\text {th }}$ International Conference on Soil Mechanics and foundation engineering", International Society of Soil Mechanics and Foundation Engineering, London, pp: 216-317, 1981.

[21] Muntohar, A.S., "Influence of Plastic waste fibers on the strength of lime- fly ash stabilized clay," Civil Engineering Dimension, Vol. 11, No. 1, pp.32- 40, 2012.

[22] Pandian, N. S., "Stabilization of expansive soil with fly ash," Proceedings of the National Symposium on Advances in Geotechnical Engineering, pp. 81-89, Karnataka Geotechnical Centre of Indian Geotechnical Society, Karnataka, India, 2004.

[23] Phanikumar, B.R., \& Sharma, R.S., "Effect of fly ash on engineering properties of expansive soil" Journal of Geotechnical and Geoenvironmental Engineering, Vol. 130, No. 7, July, pp. 764-767, 2004.

[24] Rao, K.M., "Influence of fly ash on compaction characteristics of expansive soil using $2^{2}$ factorial experimentation”, EJGE,Vol. 13,pp.01-19,2008.

[25] Senol, A., Bin-Shafique, Md. S., Edil, T. B. and Benson, C.H., "Use of Class C fly ash for stabilization of soft subgrade." Fifth International Congress on Advances in Civil Engineering, Istanbul Technical University, Turkey, 2002.

[26] Sharma, N.K. "Stabilisation of clayey soil with fly ash and lime: a micro level investigation," Geotech Geol Engg, pp. 1197-1205, 2012.

[27] Takhelmayum, G, "Laboratory study on soil stabilization using fly ash mixtures," International Journal of Engineering Science \& Innovative technology, V ol.2,Issue 1, pp 477-482, January 2013. 